\title{
Erratum to: Identification of Differentially Expressed Genes in Ducks in Response to Avian Influenza A Virus Infections
}

\author{
Marc Ndimukaga ${ }^{1}$, Kyunghye Won ${ }^{1}$, Truong Anh Duc ${ }^{2}$ and Ki-Duk Song ${ }^{1,3^{\dagger}}$ \\ ${ }^{I}$ Graduate Student, Department of Animal Biotechnology, College of Agricultural and Life Sciences, Jeonbuk National University, \\ Jeonju 54896, Republic of Korea \\ ${ }^{2}$ Senior Researcher, Department of Biochemistry and Immunology, National Institute of Veterinary Research, Hanoi 1000000, Vietnam \\ ${ }^{3}$ Professor, Animal Molecular Genetics and Breeding Center, Jeonbuk National University, Jeonju 54896, Republic of Korea
}

In the published article "Identification of Differentially Expressed Genes in Ducks in Response to Avian Influenza A Virus Infections. Korean J Poult Sci 47(1):9-19. https://doi.org/10.5536/KJPS.2020.47.1.9," the acknowlegements has to be modified. The editorial office will report that this amendment is made at the request of the author.

\section{ACKNOWLEDGMENTS}

This research was supported by the Next-Generation BioGreen 21 Program (grant numbers PJ01324201 and PJ01324203), Rural Development Administration, Republic of Korea.

\section{ORCID}

$\begin{array}{ll}\text { Marc Ndimukaga } & \text { https://orcid.org/0000-0001-8061-7753 } \\ \text { Kyunghye Won } & \text { https://orcid.org/0000-0001-8112-2840 } \\ \text { Truong Anh Duc } & \text { https://orcid.org/0000-0002-2472-8165 } \\ \text { Ki-Duk Song } & \text { https://orcid.org/0000-0003-2827-0873 }\end{array}$

\section{REFERENCES}

Ndimukaga M, Won K, Duc TA, Song KD 2020 Identification of differentially expressed genes in ducks in response to avian influenza A virus infections. Korean J Poult Sci 47(1):9-19.

\footnotetext{
${ }^{\dagger}$ To whom correspondence should be addressed : kiduk.song@jbnu.ac.kr
} 